\title{
Bioconversion of Agricultural Waste to Ethanol by SSF Using Recombinant Cellulase from Clostridium thermocellum
}

\author{
Ruchi Mutreja, ${ }^{1}$ Debasish Das, ${ }^{1}$ Dinesh Goyal, ${ }^{2}$ and Arun Goyal ${ }^{1}$ \\ ${ }^{1}$ Department of Biotechnology, Indian Institute of Technology Guwahati, Guwahati 781039, Assam, India \\ ${ }^{2}$ Department of Biotechnology and Environmental Sciences, Thaper University, Bhadson Road, Patiala 140007, Punjab, India
}

Correspondence should be addressed to Debasish Das, debasishd@iitg.ernet.in and Arun Goyal, arungoyl@iitg.ernet.in

Received 1 March 2011; Revised 20 May 2011; Accepted 21 May 2011

Academic Editor: Alane Beatriz Vermelho

Copyright ( 2011 Ruchi Mutreja et al. This is an open access article distributed under the Creative Commons Attribution License, which permits unrestricted use, distribution, and reproduction in any medium, provided the original work is properly cited.

\begin{abstract}
The effect of different pretreatment methods, temperature, and enzyme concentration on ethanol production from 8 lignocellulosic agrowaste by simultaneous saccharification and fermentation (SSF) using recombinant cellulase and Saccharomyces cerevisiae were studied. Recombinant cellulase was isolated from E. coli BL21 cells transformed with CtLic26A-Cel5-CBM11 full-length gene from Clostridium thermocellum and produced in both batch and fed-batch processes. The maximum cell OD and specific activity in batch mode were 1.6 and $1.91 \mathrm{U} / \mathrm{mg}$, respectively, whereas in the fed-batch mode, maximum cell OD and specific activity were 3.8 and $3.5 \mathrm{U} / \mathrm{mg}$, respectively, displaying a 2-fold increase. Eight substrates, Syzygium cumini (jamun), Azadirachta indica (neem), Saracens indica (asoka), bambusa dendrocalmus (bamboo), Populas nigra (poplar), Achnatherum hymenoides (wild grass), Eucalyptus marginata (eucalyptus), and Mangifera indica (mango), were subjected to SSF. Of three pretreatments, acid, alkali, and steam explosion, acid pretreatment Syzygium cumini (Jamun) at $30^{\circ} \mathrm{C}$ gave maximum ethanol yield of $1.42 \mathrm{~g} / \mathrm{L}$.
\end{abstract}

\section{Introduction}

The depleting fossil fuel resources has forced mankind to depend on the renewable energy sources, and bioethanol is one of them. Ethanol is used as a fuel, as it offers many advantages such as it has lower thermal energy content (about $45 \%$ less per gallon than diesel), low price, and with comparatively less emissions than gasoline or diesel. Ethanol has a high octane number (99) than petrol (80100) as a result of which preignition does not occur when ethanol is used. Hence, ethanol is used widely as a competitive fuel additive with gasoline and rarely in pure form $[1,2]$. Currently, biofuels such as bioethanol, biodiesel, biohydrogen, and methane from lignocellulosic biomass are produced from agrowastes rather than from energy crops, as they compete with food crops. The agricultural wastes are abundant and have disposal problem. An alternative is to utilize the lignocellulosic biomass so that the competition between food and fuel can be minimized [3]. Lignocellulosic biomass in the form of plant materials such as grass, wood, and crop residues offers the possibility of a renewable and relatively greenhouse-gas favoring source of sugars that can be converted to ethanol. The potential for using lignocellulosic materials in bioethanol production is well recognized. However, hydrolyzing lignocelluloses to fermentable reducing sugars is still a challenge, because it has a strong crystalline structure and is usually surrounded by lignin, which reduces accessibility to hydrolytic enzyme [4]. The pretreatment of lignocellulosic biomass results in substantial breakdown of the lignocellulosic structure, hydrolysis of the hemicellulosic fraction, depolymerization of the lignin components, and defibration. Different types of pretreatment methods are used such as acid, alkali, steam explosion, and ozonolysis [5]. The accessibility of cellulose components to the enzymes can be greatly enhanced by using an effective pretreatment strategy [6].

Ethanol produced from lignocellulosic biomass using separate hydrolysis and fermentation had problems as the higher concentration of reducing sugars inhibited the growth of yeast [7]. Moreover, two fermentors were required, one for hydrolysis and the other for fermentation; therefore, the process was not cost effective [7]. The solution to above problems was provided by simultaneous saccharification and fermentation (SSF) in which reducing sugars formed by 
hydrolysis are simultaneously converted into ethanol by yeast fermentation [7]. But the problem with SSF is the optimum temperature, since for enzyme hydrolysis, optimum temperature is $50^{\circ} \mathrm{C}$ and for fermentation by yeast is $30^{\circ} \mathrm{C}$, so compromised condition has to be taken for ethanol production by SSF. Extensive work has been done on ethanol production by SSF from lignocellulosic waste (LCW), such as forestry wastes, bagasse, corn stalk and cobs, wheat straw, grasses, and rice straw, using cellulase from natural and commercial sources [7-9], but there is no literature available on the use of recombinant cellulases for enzyme hydrolysis during saccharification. Jamun, eucalyptus, neem, mango, asoka, bamboo, wild grass, and poplar are among the most common crops found in north India. Also, no literature is available on the use of above-mentioned substrates for ethanol production. Due to their abundance, there is a great deal of interest in utilizing LCW for production and recovery of many valueadded products such as ethanol [8-10]. Besides the type of pretreatment method, other parameters such as enzyme activity and enzyme concentration, temperature, and $\mathrm{pH}$ affect the ethanol yield from the biomass. The present study aims at increasing the enzymatic activity of recombinant cellulase by using fed-batch strategy and increasing the ethanol yield by applying best pretreatment strategy and optimizing the enzyme concentration and temperature for SSF using S. cerevisiae.

\section{Materials and Methods}

2.1. Chemicals and Reagents. Carboxy methyl cellulose was purchased from Sigma Aldrich, USA. Sodium acetate, acetic acid, ampicillin, components of LB and GYE medium, and other reagents were purchased from HiMedia Pvt. Ltd., India.

2.2. Microorganisms and Medium. Saccahromyces cereviseae used for the production of ethanol by SSF was procured from Microbial Type Culture Collection (MTCC), Chandigarh, India. It was maintained in agar slants by storing at $4^{\circ} \mathrm{C}$ and was inoculated in GYE medium which was sterilized by autoclaving at $121^{\circ} \mathrm{C}$ for $20 \mathrm{~min}$ and was then incubated at $30^{\circ} \mathrm{C}$, $120 \mathrm{rpm} .1 \mathrm{~mL}$ of actively growing culture was transferred to $100 \mathrm{~mL}$ of culture medium. Recombinant E. coli BL21 cells transformed with plasmid containing CtLic26A-Cel5CBM11 gene from Clostridium thermocellum inserted in an expression vector pET21a was used as a source for cellulase enzyme and was developed and maintained by the group [11]. The cells were maintained as glycerol stock at $-80^{\circ} \mathrm{C}$. $200 \mu \mathrm{L}$ of the glycerol stock was transferred to $5 \mathrm{~mL}$ of $\mathrm{LB}$ medium containing $100 \mu \mathrm{g} / \mathrm{mL}$ ampicillin and incubated at $37^{\circ} \mathrm{C}, 180 \mathrm{rpm}$ for $16 \mathrm{~h} .1 \mathrm{~mL}$ of this culture was inoculated to $100 \mathrm{~mL}$ of $\mathrm{LB}$ medium containing $100 \mu \mathrm{g} / \mathrm{mL}$ ampicillin and incubated at $37^{\circ} \mathrm{C}, 180 \mathrm{rpm}$ for $12 \mathrm{~h}$.

2.3. Processing of Agrowaste Substrates. Eight different substrates were subjected to SSF study each having different cellulosic, hemicellulosic, and lignin content, namely, Syzygium cumini (jamun), Azadirachta indica (neem), Saracens indica (asoka), Bambusa dendrocalmus (bamboo), Populas nigra (poplar), Achnatherum hymenoides (wild grass), Eucalyptus marginata (eucalyptus), and Mangifera indica (mango). Leaves of jamun, mango, neem, eucalyptus, poplar, asoka, wild grass, and bamboo were supplied by Science, and Technology Entrepreneur's Park (STEP), Thaper University, Patiala, Punjab, India. Prior to pretreatment, the dry agro biomass was washed three times with water in order to remove unwanted dust particles and then air-dried at room temperature. The dry biomass was then grinded in a grinder and sieved to a mesh size of $1 \mathrm{~mm}$.

\subsection{Recombinant Cellulase Production by Batch and Fed-} Batch Process. For batch mode process, the E. coli BL-21 cells containing the recombinant cellulase were grown in $500 \mathrm{~mL}$ flask containing $250 \mathrm{~mL}$ of LB medium having $100 \mu \mathrm{g} / \mathrm{mL}$ ampicillin [11]. The dynamic profile of enzyme activity and growth was monitored by collecting sample at every $1 \mathrm{~h}$. For induction of cellulase expression, IPTG $(1 \mathrm{mM}$ final concentration) was added to the broth when the cell OD at $600 \mathrm{~nm}$ reached 0.6 . In order to enhance the enzymatic activity, the cells were grown in fed-batch mode. In the fedbatch strategy, the initial step remained the same as that for batch mode, and $245 \mathrm{~mL}$ of medium was withdrawn when the cells reached late log phase or early stationary phase. This cell mass from $245 \mathrm{~mL}$ were removed by centrifugation and processed for the isolation of crude enzyme, and the same volume of fresh medium was added and further incubated till stationary phase was reached. The same procedure was followed in consecutive four batches, where induced cells were used as inoculum. Fed-batch cultivation mode was used in order to produce maximum amount of cellulase and growth of recombinant E. coli. The enzyme was isolated by sonication of cells from both batch and fed-batch strategies.

2.5. Pretreatment of Substrates. The physically pretreated substrates were further subjected to pretreatment by steam explosion, alkali pretreatment, and acid pretreatment.

2.5.1. Steam Explosion. Steam explosion of raw material was carried out at flask level. $1 \mathrm{~g}$ of raw material was taken in the $100 \mathrm{~mL}$ flask, and then, each of the powdered substrate was subjected to sudden steam depressurization in an autoclave (15 psi, $15 \mathrm{~min}$, and $121^{\circ} \mathrm{C}$ ) by fully opening the steam exhaust valve with the objective of obtaining the maximum quantity of fermentable sugars using least pretreatment time [12].

2.5.2. Alkali Pretreatment. Each of the powdered substrates was assessed using the combined treatment with dilute alkali and autoclaving technique. $1 \mathrm{~g}$ of each substrate in $20 \mathrm{~mL}$ of $0.5 \mathrm{M} \mathrm{NaOH}$ solution was autoclaved at $115^{\circ} \mathrm{C}$ for $10 \mathrm{~min}$ [13]. After cooling, the residues were washed with sodium acetate buffer $(0.02 \mathrm{M}, \mathrm{pH} 4.3)$ and distilled water, subsequently, followed by centrifugation $(10,000 \mathrm{~g}, 10 \mathrm{~min})$ till the $\mathrm{pH}$ became neutral. The residues are dried in an oven at $70^{\circ} \mathrm{C}$ for $24 \mathrm{~h}$.

2.5.3. Acid Pretreatment. Each of the powdered substrates was assessed using the combined treatment of acid, alkali and, autoclaving techniques. $1 \mathrm{~g}$ of each substrate in $10 \mathrm{~mL}$ 
of $1 \% \mathrm{H}_{2} \mathrm{SO}_{4}$ [14] was autoclaved at $121^{\circ} \mathrm{C}$ for $15 \mathrm{~min}$ After cooling, the supernatant was decanted, and the residues were washed with $1 \% \mathrm{NaOH}$ and then with distilled water, alternatively, by first vortexing and then centrifugation at $10,000 \mathrm{~g}$ for $10 \mathrm{~min}$ till the $\mathrm{pH}$ become neutral, then the residues were dried in an oven at $70^{\circ} \mathrm{C}$ for $24 \mathrm{~h}$.

2.6. Simultaneous Saccharification and Fermentation (SSF). SSF experiments were carried out in $250 \mathrm{~mL}$ Erlenmeyer flasks, each containing $100 \mathrm{~mL}$ of fermentation medium in $0.02 \mathrm{M}$ sodium acetate buffer $(\mathrm{pH} 4.3)$ at $30^{\circ} \mathrm{C}$ on a rotary incubator shaker at $120 \mathrm{rpm}$ for $72 \mathrm{~h}$ and at $1 \%(\mathrm{w} / \mathrm{v})$ pretreated material concentration. The fermentation medium contained $1 \mathrm{~g} / \mathrm{L}$ yeast extract, $1 \mathrm{~g} / \mathrm{L}$ peptone at $4.5 \mathrm{pH}$. The production medium was supplemented with $1.0 \mathrm{~mL}$ of the recombinant cellulase obtained from E.coli in order to hydrolyze the substrate. Flasks were inoculated with $1 \%(\mathrm{v} / \mathrm{v})$ $S$. cerevisiae culture obtained by growing the organism on a rotary shaker at $120 \mathrm{rpm}$ for $48 \mathrm{~h}$ at $30^{\circ} \mathrm{C}$ in GYE medium. The samples were taken every $6 \mathrm{~h}$ and analyzed for enzyme activity, protein concentration, cell growth, glucose, and ethanol production.

2.7. Effect of Operational Parameters on SSF. The effect of temperature on ethanol production by simultaneous saccharification and fermentation process using $S$. cerevisiae was carried out by varying the temperature between $30^{\circ} \mathrm{C}-40^{\circ} \mathrm{C}$. The effect of enzyme with $1 \mathrm{~mL}, 2 \mathrm{~mL}$, and $5 \mathrm{~mL}$ having concentration $(0.55 \mathrm{mg} / \mathrm{mL})$ and specific activity of $0.52 \mathrm{U} / \mathrm{mg}$ on ethanol production was also investigated.

2.8. Analytical Methods. The enzyme assay was carried out by incubating the enzyme with substrate for $10 \mathrm{~min}$ at $50^{\circ} \mathrm{C}$. The reaction mixture $(100 \mu \mathrm{L})$ contained $10 \mu \mathrm{L}$ of supernatant containing enzyme and $1 \%$ final carboxymethyl cellulose (CMC) in $0.02 \mathrm{M}$ sodium acetate buffer, $\mathrm{pH} 4.3$. The $100 \mu \mathrm{L}$ reaction mixture was then analyzed for the release of reducing sugar using the Nelson and Somogyi, method $[15,16]$. Glucose was used as standard. Protein content was determined using $10 \mu \mathrm{L}$ of enzyme and $90 \mu \mathrm{L}$ of distilled water. To the $100 \mu \mathrm{L}$ of mixture $1 \mathrm{~mL}$ Bradford reagent was added. The reaction mixture was incubated at room temperature for $20 \mathrm{~min}$ and then analyzed spectrophotometrically at $595 \mathrm{~nm}$ [17]. BSA was used as standard. Ethanol content was estimated by using $1 \mathrm{~mL}$ cell-free supernatant to which $9 \mathrm{~mL}$ distilled water and $1 \mathrm{~mL}$ dichromate was added and heated for $10 \mathrm{~min}$ in boiling water bath. During heating, ethanol was converted to acid on reaction with dichromate and resulted in colour change from orange to green which can be analysed spectrophotometrically at $600 \mathrm{~nm}$ [18]. Ethanol was used as standard.

\section{Results and Discussion}

3.1. Production and Enhancement of Recombinant Cellulase from E. Coli. The maximum OD, enzyme activity, and specific activity obtained in batch mode were $1.62,0.136 \mathrm{U} / \mathrm{mL}$, and $1.91 \mathrm{U} / \mathrm{mg}$, respectively, as shown in Figure 1(a). In the fed-batch mode, maximum OD, enzyme activity, and specific activity obtained was $3.78,0.301 \mathrm{U} / \mathrm{mL}$, and $3.52 \mathrm{U} / \mathrm{mg}$, respectively, as shown in Figure 1(b). Thus, the fed-batch cultivation of $E$. coli containing recombinant enzyme displayed two-fold increase in biomass productivity, the enzyme activity, and specific activity in comparison to a batch cultivation process. During fed-batch mode, already induced cells were used as inoculum for the consecutive batches due to which more protein expression was observed and due to further induction by the addition of IPTG more recombinant enzyme was produced.

\subsection{Ethanol Production by SSF from Substrates Using Different} Pretreatment. The solid residues of various substrates were subjected to SSF process by $S$. cerevisiae at a temperature of $30^{\circ} \mathrm{C}$ and $1.0 \%$ substrate concentration after pretreatment. The pretreated substrates were hydrolyzed enzymatically by recombinant cellulase isolated from recombinant $E$. coli cells. All pretreatments were efficient for delignification of the lignocellulosic biomass. The effect of different pretreatments on ethanol production is shown in Table 1. In all cases of substrates, low-reducing sugar contents were obtained with good yeast fermentation performance. Depending on the amount of ethanol produced, acid pretreatment was found to be the best of all pretreatment methods carried out. Recent studies have shown that when acids are combined with alkali, they play more effective role in LCW pretreatment than acids or alkalis alone [19]. Using steam explosion as pretreatment, maximum ethanol was produced in case of eucalyptus $(0.53 \mathrm{~g} / \mathrm{L})$ with a yield coefficient of 0.053 followed by jamun $(0.46 \mathrm{~g} / \mathrm{L}$ ethanol) and yield coefficient of 0.046 (Table 1$)$. Using alkali pretreatment method maximum ethanol was obtained in case of bamboo $(0.83 \mathrm{~g} / \mathrm{L})$ with a yield coefficient of 0.083 followed by wild grass $(0.77 \mathrm{~g} / \mathrm{L}$ ethanol $)$ and yield coefficient of 0.077 (Table 1). Using acid method as a pretreatment strategy, maximum ethanol was obtained in case of jamun $(1.22 \mathrm{~g} / \mathrm{L})$ with a yield coefficient of 0.122 followed by wild Grass $(0.78 \mathrm{~g} / \mathrm{L})$ with a yield coefficient of 0.078 as shown in Table 1 . Hence, acid pretreatment gave best results of the three different pretreatments carried out, as in case of acid pretreatment both acid and alkali are used, which resulted in higher delignification of the substrates. By acid pre-treatment, the structure of substrate becomes less complex, and it becomes more accessible to the enzyme, and hence, more reducing sugars are released. These sugars are then converted to ethanol by yeast, the fermenting organism. The ethanol concentration of $21 \mathrm{~g} / \mathrm{L}$ was obtained using commercial cellulolytic enzyme and $10 \%(\mathrm{w} / \mathrm{v})$ substrate (sunflower stalks), that is, $2.1 \mathrm{~g} / \mathrm{L}$ ethanol concentration with $1 \%$ substrate [20]. Kinnow waste and banana peels were used as substrates in the ratio of 6: 4, and total $25 \mathrm{~g}$ biomass was obtained $26.84 \mathrm{~g} / \mathrm{L}$ ethanol, that is, $1.074 \mathrm{~g} / \mathrm{L}$ ethanol by using $1 \mathrm{~g}$ of biomass [12]. Using baggase as substrate the ethanol yield of $0.13-0.18$ [21] and 0.116 [22] were obtained which are comparable to our findings. The ethanol concentration of $22 \mathrm{~g} / \mathrm{L}$ was obtained using coculture of Clostridium thermosaccharolyticum HG8 and Thermoanaerobacter ethanolicus ATCC 31937 with $100 \mathrm{~g} / \mathrm{L}$ banana waste as substrate, that is, $2.2 \mathrm{~g} / \mathrm{L}$ of ethanol from $1 \%$ of substrate [14]. All these results are comparable with our 
TABLE 1: Effect of different pretreatment methods on ethanol production by SSF.

\begin{tabular}{|c|c|c|c|c|c|c|c|c|c|}
\hline \multirow{2}{*}{ Substrates } & \multicolumn{3}{|c|}{ Steam explosion } & \multicolumn{3}{|c|}{ Alkali pretreatment } & \multicolumn{3}{|c|}{ Acid pretreatment } \\
\hline & Cell OD & $\begin{array}{c}\text { Ethanol } \\
(\mathrm{g} / \mathrm{L})\end{array}$ & $\begin{array}{l}\text { Yield } \\
(\mathrm{P} / \mathrm{S})\end{array}$ & Cell OD & $\begin{array}{c}\text { Ethanol } \\
(\mathrm{g} / \mathrm{L})\end{array}$ & Yield (P/S) & CellOD & $\begin{array}{c}\text { Ethanol } \\
(\mathrm{g} / \mathrm{L})\end{array}$ & $\begin{array}{l}\text { Yield } \\
(\mathrm{P} / \mathrm{S})\end{array}$ \\
\hline $\begin{array}{l}\text { Saracens indica } \\
\text { (Asoka) }\end{array}$ & 0.936 & 0.402 & 0.040 & 1.357 & 0.661 & 0.066 & 1.343 & 0.670 & 0.067 \\
\hline $\begin{array}{l}\text { Achnatherum } \\
\text { hymenoides } \\
\text { (Wild grass) }\end{array}$ & 0.606 & 0.245 & 0.024 & 1.362 & 0.770 & 0.077 & 1.283 & 0.780 & 0.078 \\
\hline $\begin{array}{l}\text { Mangifera } \\
\text { indica } \\
\text { (Mango) }\end{array}$ & 0.859 & 0.241 & 0.024 & 1.369 & 0.658 & 0.066 & 1.32 & 0.612 & 0.061 \\
\hline $\begin{array}{l}\text { Syzygium } \\
\text { cumini } \\
\text { (Jamun) }\end{array}$ & 0.719 & 0.461 & 0.046 & 1.376 & 0.727 & 0.073 & 1.316 & 1.216 & 0.122 \\
\hline $\begin{array}{l}\text { Azadirachta } \\
\text { indica (Neem) }\end{array}$ & 0.595 & 0.292 & 0.029 & 1.382 & 0.608 & 0.061 & 1.29 & 0.705 & 0.071 \\
\hline $\begin{array}{l}\text { Populas nigra } \\
\text { (Poplar) }\end{array}$ & 0.880 & 0.323 & 0.033 & 1.369 & 0.665 & 0.067 & 1.32 & 0.590 & 0.059 \\
\hline $\begin{array}{l}\text { Eucalyptus } \\
\text { marginata } \\
\text { (Eucalyptus) }\end{array}$ & 0.726 & 0.535 & 0.054 & 1.339 & 0.624 & 0.062 & 1.28 & 0.760 & 0.076 \\
\hline $\begin{array}{l}\text { Bambusa } \\
\text { dendrocalmus } \\
\text { (Bamboo) }\end{array}$ & 0.909 & 0.263 & 0.026 & 1.376 & 0.834 & 0.083 & 1.286 & 0.554 & 0.055 \\
\hline
\end{tabular}

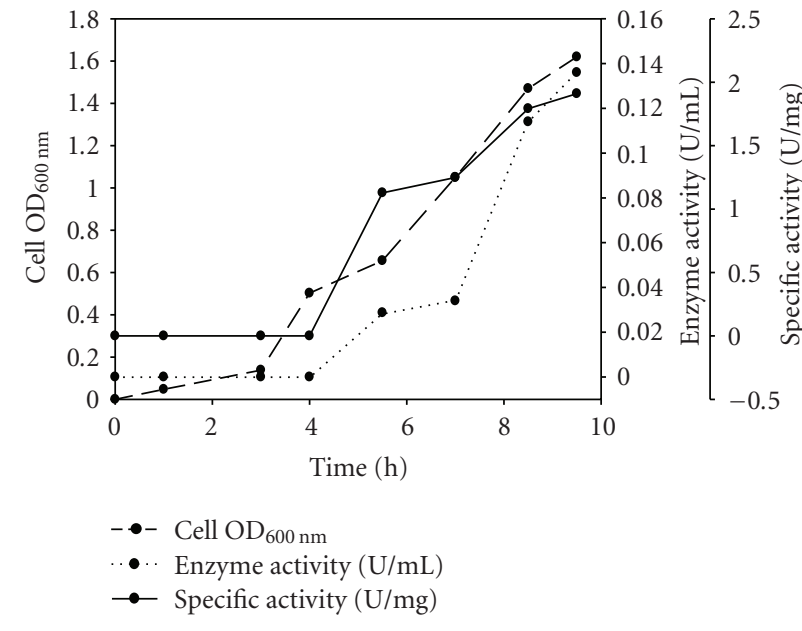

(a)

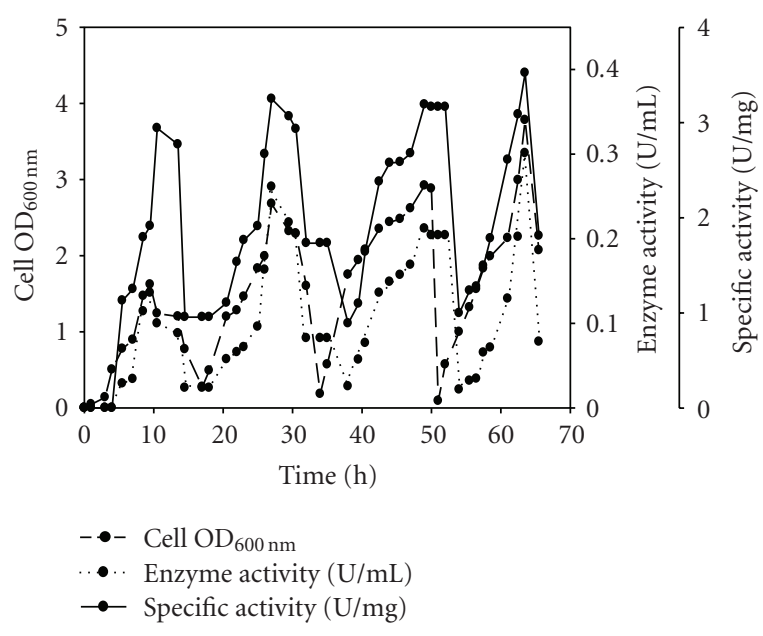

(b)

FIGURE 1: Dynamic profile of cell growth, enzyme activity, and specific activity with time in (a) batch experiment (b) fed-batch experiment.

findings though we are using recombinant enzyme which is cost effective as compared to above mentioned methods.

\subsection{Effect of Temperature and Enzyme Concentration on} Ethanol Production by SSF. Since acid pretreatment gave the best results out of three pretreatments, so for temperature optimization using acid pretreatment was done for SSF. Four substrates, jamun, bamboo, eucalyptus, and wild grass, were selected for optimization, since these gave better results over as compared to other substrates. The effect of temperature on ethanol production by simultaneous saccharification and fermentation using $S$. cerevisiae was studied at temperatures $30^{\circ} \mathrm{C}, 35^{\circ} \mathrm{C}$ and $40^{\circ} \mathrm{C}$. Maximum ethanol was obtained with Syzygium cumini (Jamun) as a substrate at $30^{\circ} \mathrm{C}$ (Figure 2 ). Using jamun as a substrate ethanol obtained at $30^{\circ} \mathrm{C}, 35^{\circ} \mathrm{C}$, and $40^{\circ} \mathrm{C}$ was $1.2 \mathrm{~g} / \mathrm{L}, 0.46 \mathrm{~g} / \mathrm{L}$ and $0.41 \mathrm{~g} / \mathrm{L}$, respectively. However, at temperatures higher than $30^{\circ} \mathrm{C}$ showed a fall in ethanol production which is consistent with the findings of El-Refai et al. [23] who reported maximum ethanol productivity from beet molasses by $S$. cerevisiae Y-7. The temperature, $30^{\circ} \mathrm{C}$ has been also reported as optimum for maximum ethanol production using starch employing 

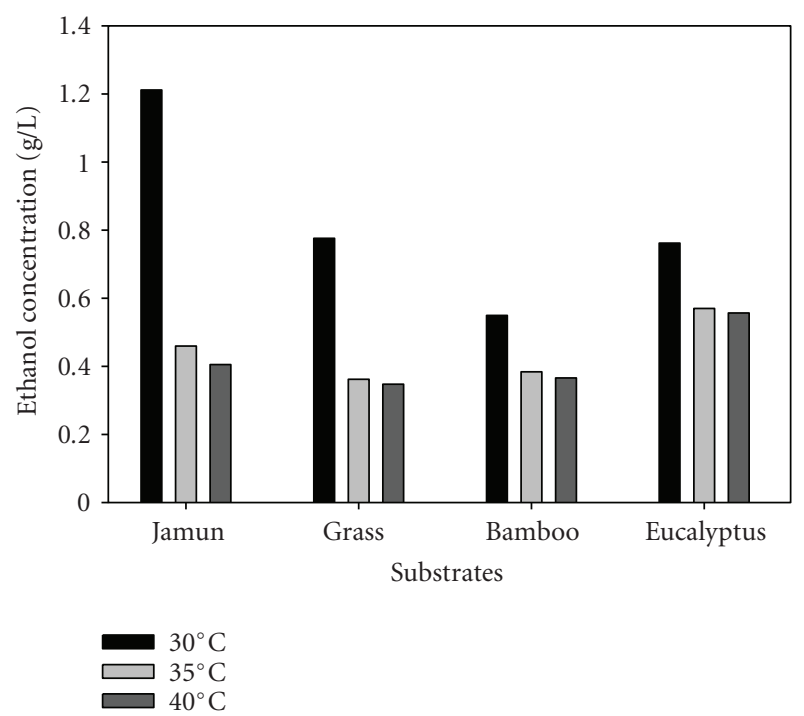

FIGURE 2: Effect of temperature on ethanol production by SSF, using different lignocellulosic biomass using acid pretreatment.

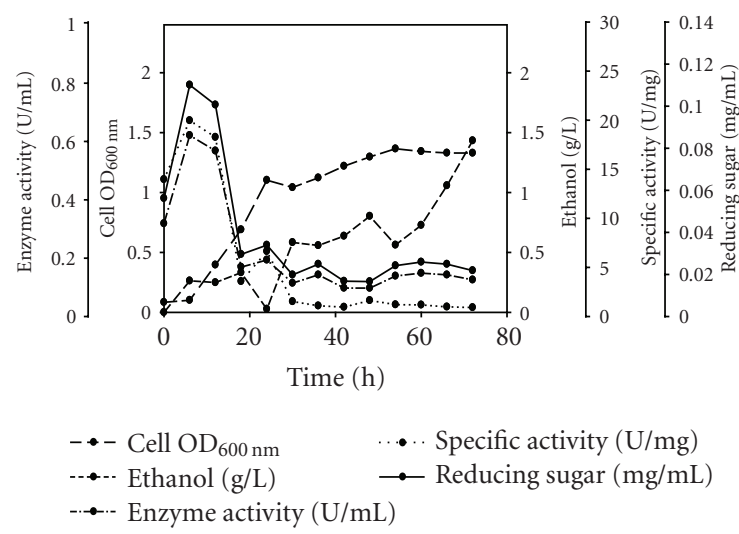

FIGURE 3: Ethanol production by SSF using optimized parameters using Syzygium cumini (Jamun) as a substrate.

coculture of amylolytic yeast and S. cerevisiae [24]. These observations are consistent with findings of other authors $[25,26]$. The future experiments were conducted at incubation temperature of $30^{\circ} \mathrm{C}$. The effect of crude cellulase $1 \mathrm{~mL}, 2 \mathrm{~mL}$, and $5 \mathrm{~mL}(0.53 \mathrm{U} / \mathrm{mg}, 0.55 \mathrm{mg}$ protein $/ \mathrm{mL})$ on ethanol production was investigated. Using jamun, ethanol obtained at $1 \mathrm{~mL}, 2 \mathrm{~mL}$, and $5 \mathrm{~mL}$ enzyme concentration was $1.26 \mathrm{~g} / \mathrm{L}, 1.27 \mathrm{~g} / \mathrm{L}$, and $1.43 \mathrm{~g} / \mathrm{L}$, respectively, showing no significant effect of enzyme concentration on ethanol production (Figure 3). The enzymatic hydrolysis of the solid fraction has large control over total rate of ethanol production in SSF [27, 28]. Studies in which the enzyme loading has been varied showed strong positive correlation between enzyme loading and the overall ethanol yield [29, 30].

3.4. Effect of Cell Growth on Ethanol Production. S. cerevisiae stays in the lag phase during the initial 12 to $16 \mathrm{~h}$ from inoculation due to the unavailability of utilizable sugars in the medium. Hydrolysis of the complex cellulose takes place during the initial $18 \mathrm{~h}$ in which the organism lies in the lag phase of growth. Cellobiose is the direct product of the cellulose activity which is an inhibitor of the enzyme. Kovacs et al. [31] report the need to supplement commercial cellulases used in SSF process with $\beta$-glucosidase and also observed the accumulation of cellobiose nearly to $10 \mathrm{~g} \mathrm{~L}^{-1}$ during the first $10 \mathrm{~h}$ of fermentation, when using the bakery $S$. cerevisiae strain for bioethanol production in SSF process with sugarcane bagasse, and had to add additional $\beta$-glucosidase in their experiments to reduce the cellobiose concentration. For next $24 \mathrm{~h}$, S.cerevisiae enters the log phase utilizing the consumable sugars derived from cellulose, which, in turn, increased the percentage of ethanol produced during fermentation. Ethanol production reaches the maximum during the stationary phase of the organism. Maximum amount of reducing sugar was obtained in the lag phase and then in the stationary phase which was utilized for the growth and maintenance of the microorganism, respectively. SSF profile of jamun using acid pretreatment at $30^{\circ} \mathrm{C}$ is shown in Figure 3.

\section{Conclusion}

The use of recombinant cellulase for bioethanol production is a strategy to reduce the enzyme cost. The in vitro cellulase production and activity can be enhanced using the fed-batch mode. This study could establish that the agricultural wastes which have considerable disposal problem can be used for ethanol production through the process of simultaneous saccharification and fermentation. Thus, the present study opens new possibilities of exploiting leafy litter commercially for industrial applications. There is certainly the scope of enhancing the ethanol yield by process optimization. The process with optimized fermentation conditions can then be used for scaling up to the pilot scale.

\section{Acknowledgment}

The research work was supported by a joint project grant from Department of Biotechnology, Ministry of Science and Technology, New Delhi, India, to A. Goyal and D. Goyal.

\section{References}

[1] M. E. Oliveira, B. E. Vaughan, and E. J. Rykiel, "Ethanol as fuel: energy, carbon dioxide balances, and ecological footprint," BioScience, vol. 55, no. 7, pp. 593-602, 2005.

[2] H. Shapouri and P. Gallagher, "USDA's 2002 ethanol cost-ofproduction survey," USDA Agricultural Economic Report 841, 2009, http://www.usda.gov/oce/reports/energy/USDA_2002_ ETHANOL.pdf.

[3] B. Mahro and M. Timm, "Potential of biowaste from the food industry as a biomass resource," Engineering in Life Sciences, vol. 7, no. 5, pp. 457-468, 2007.

[4] C. N. Hamelinck, G. F. Van Hooijdonk, and A. P. C. Faaij, "Ethanol from lignocellulosic biomass: techno-economic performance in short-, middle- and long-term," Biomass and Bioenergy, vol. 28, no. 4, pp. 384-410, 2005. 
[5] G. Y. S. Mtui, "Recent advances in pretreatment of lignocellulosic wastes and production of value added products," African Journal of Biotechnology, vol. 8, no. 8, pp. 1398-1415, 2009.

[6] M. Moniruzzaman, "Effect of steam explosion on the physicochemical properties and enzymatic saccharification of rice straw," Applied Biochemistry and Biotechnology, vol. 59, no. 3, pp. 283-297, 1996.

[7] O. Kim, B. Magnus, and L. Gunnar, "A short review on SSFan interesting process option for ethanol production from lignocellulosic feedstocks," Biotechnology for Biofuels, vol. 1, p. 7, 2008.

[8] A. Pandey, C. R. Soccol, P. P. Nigam, and V. T. Soccol, "Biotechnological potential of agro-industrial residues. I: sugarcane bagasse," Bioresource Technology, vol. 7, no. 1, pp. 69-80, 2000.

[9] H. Das and S. Singh, "Useful byproducts from cellulosic wastes of agriculture and food industry—a critical appraisal," Critical Reviews in Food Science and Nutrition, vol. 44, no. 2, pp. 77-89, 2004.

[10] T. Foyle, L. Jennings, and P. Mulcahy, "Compositional analysis of lignocellulosic materials: evaluation of methods used for sugar analysis of waste paper and straw," Bioresource Technology, vol. 98, no. 16, pp. 3026-3036, 2007.

[11] E. J. Taylor, A. Goyal, C. I. P. D. Guerreiro et al., "How family 26 glycoside hydrolases orchestrate catalysis on different polysaccharides: structure and activity of a Clostridium thermocellum lichenase, CtLic26A," Journal of Biological Chemistry, vol. 280, no. 38, pp. 32761-32767, 2005.

[12] N. Sharma, K. L. Kalra, H. S. Oberoi, and S. Bansal, "Optimization of fermentation parameters for production of ethanol from kinnow waste and banana peels by simultaneous saccharification and fermentation," Indian Journal of Microbiology, vol. 47, no. 4, pp. 310-316, 2007.

[13] B. C. Okeke and S. K. C. Obi, "Saccharification of agrowaste materials by fungal cellulases and hemicellulases," Bioresource Technology, vol. 51, no. 1, pp. 23-27, 1994.

[14] H. K. Reddy, M. Srijana, M. D. Reddy, and G. Reddy, "Coculture fermentation of banana agro-waste to ethanol by cellulolytic thermophilic Clostridium thermocellum CT2," African Journal of Biotechnology, vol. 9, no. 13, pp. 1926-1934, 2010.

[15] N. Nelson, "A photometric adaptation of the Somogyi method for the determination of glucose," Journal of Biological Chemistry, vol. 153, pp. 375-380, 1944.

[16] M. Somogyi, "A new reagent for the determination of sugars," Journal of Biological Chemistry, vol. 160, no. 1, pp. 61-68, 1945.

[17] M. M. Bradford, "A rapid and sensitive method for the quantitation of microgram quantities of protein utilizing the principle of protein dye binding," Analytical Biochemistry, vol. 72, no. 1-2, pp. 248-254, 1976.

[18] H. B. Seo, H. J. Kim, and H. K. Jung, "Measurement of ethanol concentration using solvent extraction and dichromate oxidation and its application to bioethanol production process," Journal of Industrial Microbiology and Biotechnology, vol. 36, no. 2, pp. 285-292, 2009.

[19] D. Damisa, J. Ameh, and V. J. Umoh, "Effect of chemical pretreatment of some lignocellulosic wastes on the recovery of cellulase from Aspergillus niger AH3 mutant," African Journal of Biotechnology, vol. 7, no. 14, pp. 2444-2450, 2008.

[20] E. Ruiz, C. Cara, M. Ballesteros, P. Manzanares, I. Ballesteros, and E. Castro, "Ethanol production from pretreated olive tree wood and sunflower stalks by an SSF process," Applied Biochemistry and Biotechnology, vol. 129-132, no. 1-3, pp. 631-643, 2006.

[21] J. M. Hernandez-Sales, M. S. Villa-Ramirez, J. S. Veloz-Rendon et al., "Comparative hydrolysis and fermentation of sugarcane and agave bagasse," Bioresource Technology, vol. 100, pp. 1238$1245,2009$.

[22] C. Martín, H. B. Klinke, and A. B. Thomsen, "Wet oxidation as a pretreatment method for enhancing the enzymatic convertibility of sugarcane bagasse," Enzyme and Microbial Technology, vol. 40, no. 3, pp. 426-432, 2007.

[23] A. H. El-Refai, M. S. El-Abyad, A. I. El-Diwany, L. A. Sallam, and R. F. Allam, "Some physiological parameters for ethanol production from beet molasses by Saccharomyces cerevisiae Y7," Bioresource Technology, vol. 42, no. 3, pp. 183-189, 1992.

[24] G. Verma, P. Nigam, D. Singh, and K. Chaudhary, "Bioconversion of starch to ethanol in a single-step process by coculture of amylolytic yeasts and Saccharomyces cerevisiae," Bioresource Technology, vol. 72, no. 3, pp. 261-266, 2000.

[25] S. Sánchez, V. Bravo, A. J. Moya, E. Castro, and F. Camacho, "Influence of temperature on the fermentation of D-xylose by Pachysolen tannophilus to produce ethanol and xylitol," Process Biochemistry, vol. 39, no. 6, pp. 673-679, 2004.

[26] M. S. El-Abyad, A. H. El-Refai, A. I. El-Diwany, L. A. Sallam, and R. F. Allam, "Effect of some fermentation parameters on ethanol production from beet molasses by Saccharomyces cerevisiae Y-7," Bioresource Technology, vol. 42, no. 3, pp. 191195, 1992.

[27] A. Rudolf, M. Alkasrawi, G. Zacchi, and G. Lidén, "A comparison between batch and fed-batch simultaneous saccharification and fermentation of steam pretreated spruce," Enzyme and Microbial Technology, vol. 37, no. 2, pp. 195-205, 2005.

[28] P. Sassner, M. Galbe, and G. Zacchi, "Bioethanol production based on simultaneous saccharification and fermentation of steam-pretreated Salix at high dry-matter content," Enzyme and Microbial Technology, vol. 39, no. 4, pp. 756-762, 2006.

[29] M. Linde, M. Galbe, and G. Zacchi, "Simultaneous saccharification and fermentation of steam-pretreated barley straw at low enzyme loadings and low yeast concentration," Enzyme and Microbial Technology, vol. 40, no. 5, pp. 1100-1107, 2007.

[30] R. Eklund and G. Zacchi, "Simultaneous saccharification and fermentation of steam-pretreated willow," Enzyme and Microbial Technology, vol. 17, no. 3, pp. 255-259, 1995.

[31] K. Kovacs, M. Stefano, S. George, and Z. Guido, "Enzymatic hydrolysis of steam-pretreated lignocellulosic materials with Trichoderma atroviride Trichoderma atroviride enzymes produced in-house," Biotechnology for Biofuels, vol. 2, p. 14, 2009. 

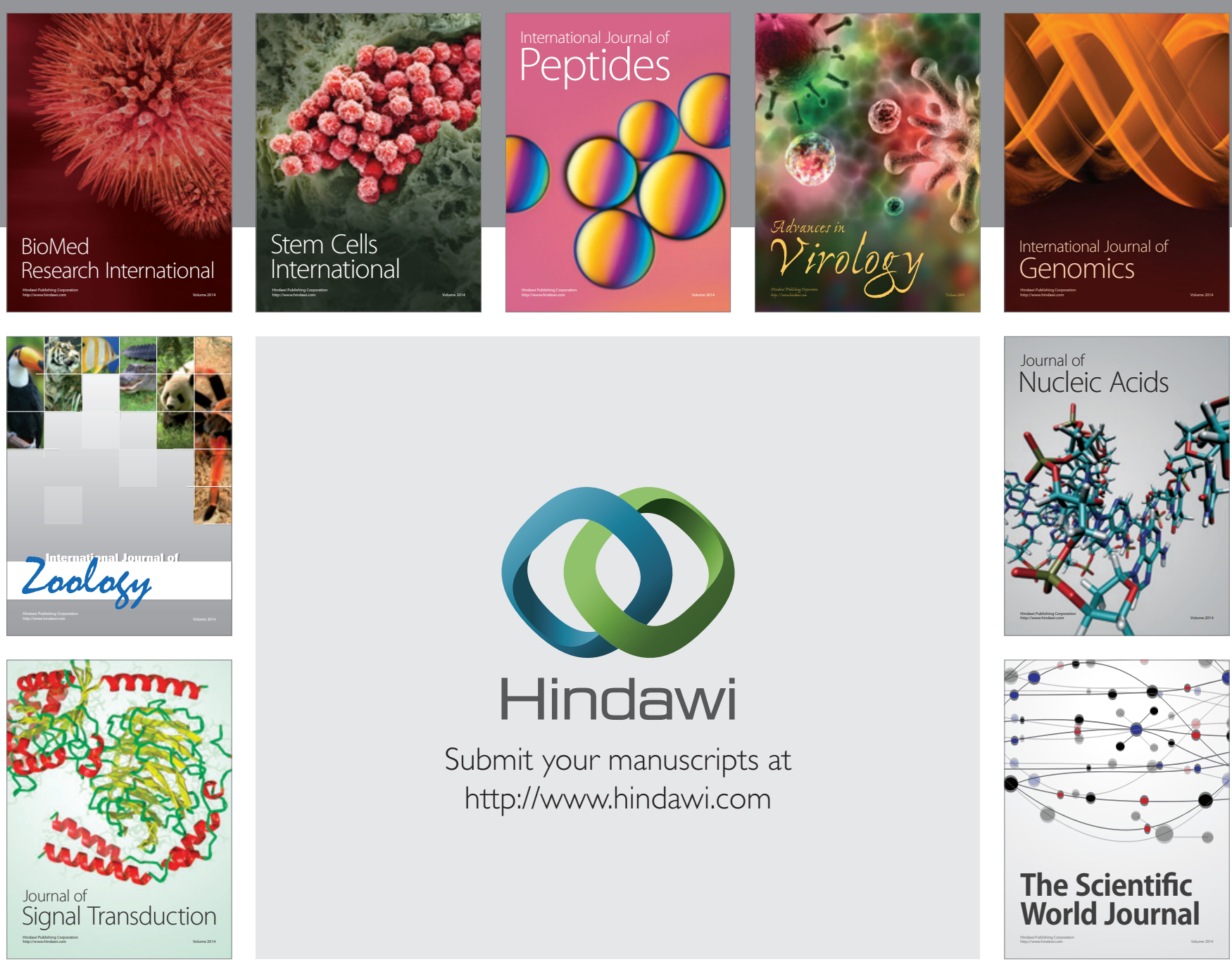

Submit your manuscripts at

http://www.hindawi.com
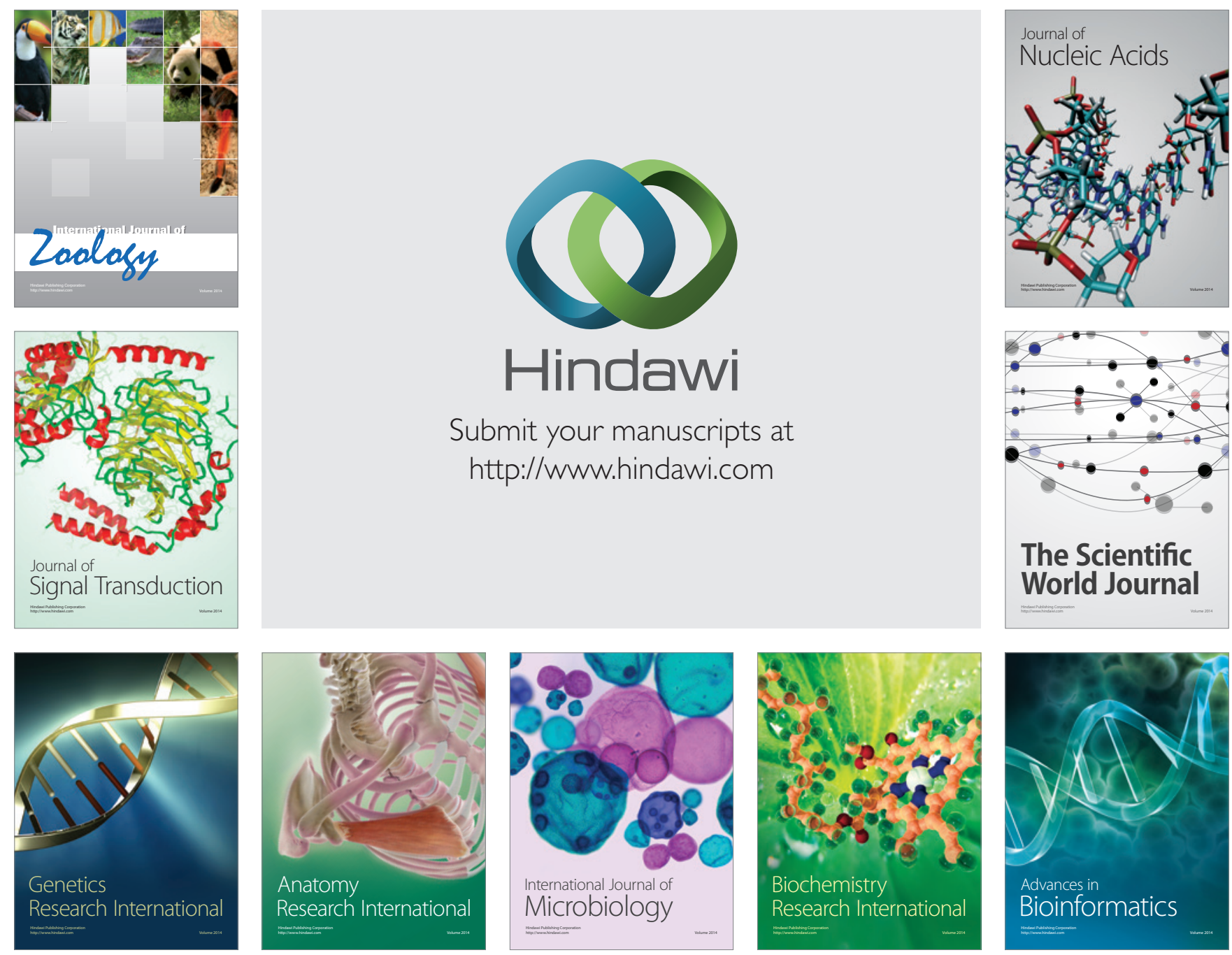

The Scientific World Journal
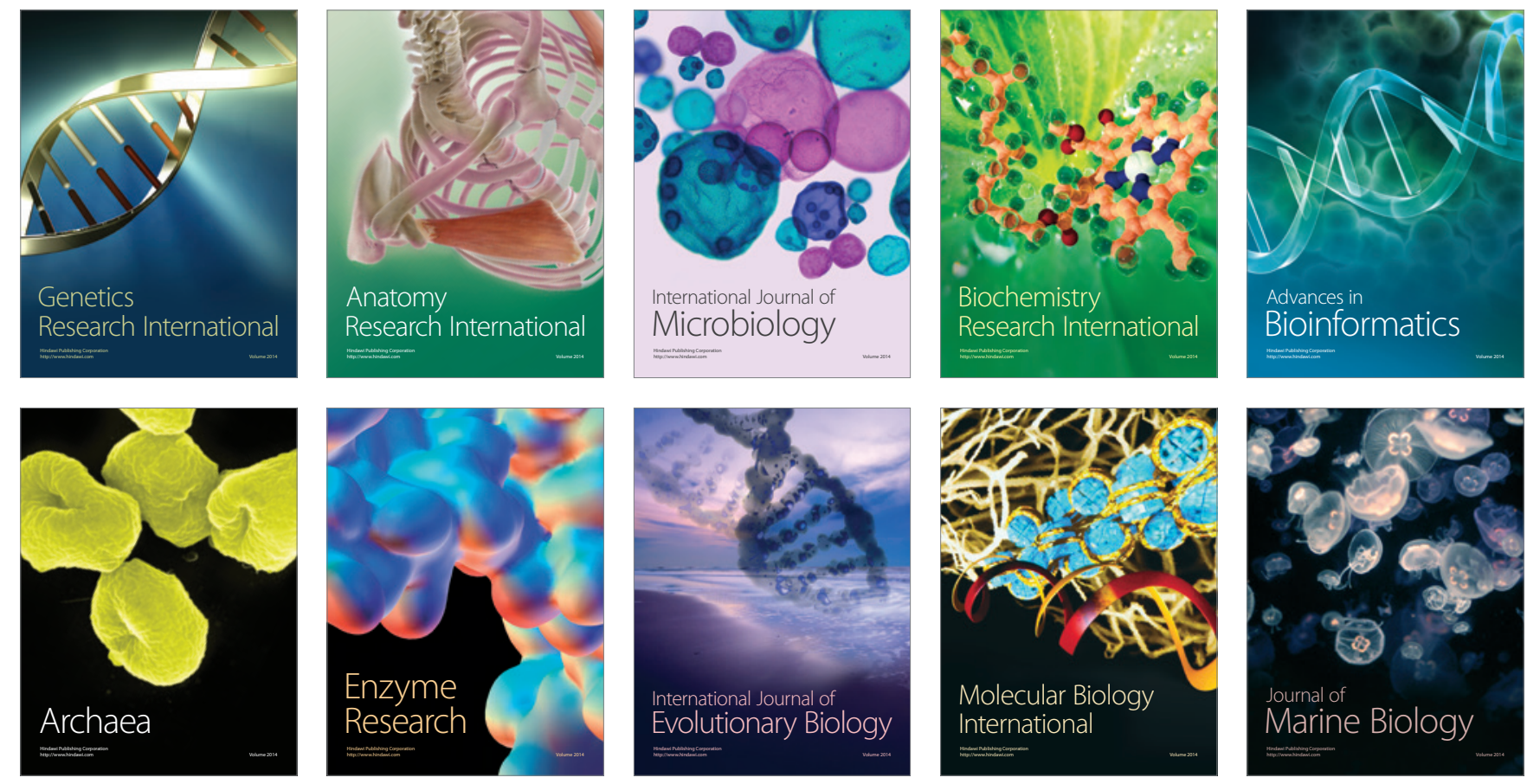